\title{
Dual processes for cross-boundary subsidies: incorporation of nutrients from reef-derived kelp into a seagrass ecosystem
}

\author{
Glenn A. Hyndes ${ }^{1, *}$, Paul S. Lavery ${ }^{1}$, Christopher Doropoulos ${ }^{2}$ \\ ${ }^{1}$ Centre for Marine Ecosystems Research, School of Natural Sciences, Edith Cowan University, 270 Joondalup Drive, \\ Joondalup, Western Australia 6027, Australia \\ ${ }^{2}$ School of Biological Sciences and ARC Centre of Excellence for Coral Reef Studies, The University of Queensland, \\ Brisbane, Queensland 4072, Australia
}

\begin{abstract}
Movement of organic material across ecosystem boundaries can be critical for subsidizing production in recipient systems, particularly in systems with low in situ productivity or resource availability. Yet, what happens in highly productive and resource-rich ecosystems? Kelp, which is dislodged in high quantities in temperate regions, can accumulate in seagrass ecosystems where productivity and resource availability are high. Using an experimental approach of adding isotopically-labelled $\left({ }^{15} \mathrm{~N}\right)$ kelp in laboratory and field experiments, we tested whether allochthonous kelp could be incorporated into seagrass ecosystems via (1) the uptake of leached nutrients by macrophytes and (2) the assimilation of nutrients by consumers. Seagrass and epiphytes assimilated kelp- ${ }^{15} \mathrm{~N}$ under laboratory and field conditions, with epiphytes showing a greater rate of uptake than the seagrass leaves. Unlabelled kelp leached 1225 and $736 \mu \mathrm{g} \mathrm{N}(100 \mathrm{~g} \mathrm{kelp})^{-1} \mathrm{~d}^{-1}$ of dissolved organic nitrogen from freshly detached and 2 wk old kelp, respectively. Mesograzers (gastropods) assimilated kelp $-{ }^{15} \mathrm{~N}$ under laboratory and field conditions, despite the presence of alternative food sources. We conclude that reef-derived kelp can act as an important vector of nutrient and energy transfer to both primary producers and consumers in marine landscapes, regardless of their levels of productivity and resource availability.
\end{abstract}

KEY WORDS: Food webs · Trophic subsidies $\cdot$ Posidonia $\cdot$ Ecklonia $\cdot$ Detritus $\cdot$ Spatial ecology

\section{INTRODUCTION}

Understanding fluxes of materials, organisms and energy across ecosystem boundaries at the landscape scale is fundamental to ecology. Since the pioneering work of Polis et al. (1997), several studies have demonstrated empirically that the movement of animals (Polis et al. 1997, Baxter et al. 2004) or detritus (Bustamante et al. 1995, Wallace et al. 1999, McLeod \& Wing 2007) within and between terrestrial and aquatic environments can play an integral role in foodweb dynamics, community structure, and productivity in recipient systems. From their metaanalysis, Marczak et al. (2007) concluded that the degree to which imported material influences recipi- ent ecosystems depends on that system's characteristics, including the level of ambient food resources and the type of consumers, even though they acknowledged their study was biased towards a restricted number of ecosystem boundaries. The majority of studies have focused on the transfer of resources from aquatic to terrestrial or terrestrial to aquatic ecosystems (Polis et al. 1997, Wallace et al. 1999, Orr et al. 2005), but generalities derived from those studies may not apply to other ecosystems and could bias ecological theory regarding those landscape processes.

Detritus plays a central role in community organisation but has tended to be ignored in generalizations of food webs and trophodynamics (Moore et al. 
2004). Food-web structure in aquatic systems can be altered by, and in some cases is reliant on, allochthonous detritus. Terrestrial-derived litter drives secondary production in many streams (e.g. Wallace et al. 1999, Kohzu et al. 2004) and contributes to food webs in fjords (McLeod \& Wing 2007), while marinederived macrophytes can drive production on beaches and islands (Polis et al. 1997) and in surf and intertidal zones (e.g. Bustamante et al. 1995, Crawley et al. 2009). However, these examples of spatial subsidies all represent the movement of material into recipient systems with relatively low in situ production and resource availability (see Marczak et al. 2007). Yet, some studies indicate that other vectors of organic matter (e.g. fish and insects) can supply subsidies in productive ecosystems such as forests (e.g. Gende \& Willson 2001, Mellbrand et al. 2011).

Kelp (laminarian brown algae) is a major primary producer in temperate coastal systems (Dayton 1985) and, once removed from reefs, forms rafts on the ocean's surface (e.g. Hobday 2000) or wrack along shorelines (Orr et al. 2005, Crawley et al. 2009). Grazing on kelp by mesograzers can be high (Bustamante et al. 1995). Furthermore, degradation rates of kelp can be high (Kirkman \& Kendrick 1997, Pedersen et al. 2005), leading to the release of large amounts of dissolved nutrients into the water column (Valiela et al. 1997) that are potentially available to primary producers (Vonk et al. 2008). Thus, imported kelp has the potential to enhance productivity in recipient systems via 2 pathways: increasing food availability to consumers and enhancing primary production through the provision of dissolved bioavailable nutrients.

Seagrass meadows provide an ideal model system to examine pathways for the potential subsidies provided by allochthonous resources on the productivity in productive systems. They rank amongst the most productive marine ecosystems (Mateo et al. 2006) and provide habitat for a diverse assemblage of epiphytes, invertebrates and fish (Orth et al. 2006). However, they often occur in oligotrophic waters (Romero et al. 2006) and export large amounts of nutrients to other systems via the movement of shedding leaves and fauna (Heck et al. 2008). Seagrasses access nutrients from the sediments and water column, with nutrient concentrations in the sediments being high but not necessarily bioavailable (Cambridge \& Hocking 1997). Nutrients from allochthonous kelp could play an important role in sustaining seagrass ecosystems because this reef-derived material is transported into seagrass meadows in large quantities (Wernberg et al. 2006), is consumed by mesograzers (Duffy \& Hay 2000), and releases nutrients directly during degradation processes (Kirkman \& Kendrick 1997, Pedersen et al. 2005) or through excretion via consumers. We hypothesized that seagrass ecosystems in an oligotrophic environment will take up nutrients from allochthonous kelp and sought to detemine if those nutrients were taken up directly by consumers and/or primary producers. To test whether allochthonous kelp has the potential to subsidize seagrass ecosystems and clarify potential pathways of such subsidies, we adopted an approach using additions of the isotopic tracer ${ }^{15} \mathrm{~N}$ to trace the assimilation of kelp-nitrogen into seagrass and its epiphytes as well as mesograzers in uptake in laboratory and field experiments. This approach overcame any issues related more to ambiguous stable isotope data caused by highly variable and overlapping stable isotope values from a range of potential nutrient sources. For example, Smit et al. $(2005,2006)$ used stable isotopes to show that macroalgae were likely to be the major source of carbon to higher trophic levels, but they were unable to differentiate autochthonous and allochthonous resources.

\section{MATERIALS AND METHODS}

\section{Study region and sample collection}

Limestone reefs dominated by a canopy of the kelp Ecklonia radiata occur along the southwest coast of Australia (Wernberg et al. 2003), where the kelp occur at average densities of 20 to 80 plants $\mathrm{m}^{-2}$ in the region (Kendrick et al. 1999). Annual production can be as high as $3500 \mathrm{~g}$ dry wt $\mathrm{m}^{-2} \mathrm{yr}^{-1}$ (Kirkman 1984). Kelp typically detaches from reefs in autumn and winter, forming a major component of the wrack along the coastline and in seagrass meadows (Crawley et al. 2006, Wernberg et al. 2006). Large meadows of the seagrass Posidonia sinuosa Cambridge \& Kuo, 1979 occur inshore of these reefs, where leaf and epiphyte production range from 600 to 900 and 133 to $161 \mathrm{~g} \mathrm{dry} \mathrm{wt} \mathrm{m}^{-2}$ $\mathrm{yr}^{-1}$, respectively (Cambridge \& Hocking 1997). Mesograzers are abundant in seagrass systems of the region (Jernakoff \& Nielsen 1997), with Cantharidus lepidus Phillipi, 1849 being a common and abundant gastropod in the region's Posidonia meadows (Tuya et al. 2010) where it feeds on epiphytic algae (Doropoulos et al. 2009).

We used a series of field and laboratory experiments to examine the uptake of ${ }^{15} \mathrm{~N}$ from the kelp Ecklonia radiata in a Posidonia sinuosa seagrass sys- 
tem during late February to April 2008. Field experiments took place in a large $P$. sinuosa meadow fringed by offshore reefs in Shoalwater Islands Marine Park (SIMP), south-western Australia $\left(32^{\circ} 16^{\prime} \mathrm{S}, 115^{\circ} 41^{\prime} \mathrm{E}\right)$. E. radiata is abundant on the reefs offshore from the seagrass site, and detached kelp was observed to be a feature of the seagrass meadow and the nearby shoreline where kelp wrack was regularly present. Leaves of $P$. sinuosa and individuals of the mesograzer Cantharidus lepidus (9 to $15 \mathrm{~mm}$ in shell length) were collected from SIMP, while E. radiata was collected $60 \mathrm{~km}$ to the north from Marmion Marine Park (31 $49.4^{\prime} \mathrm{S}, 115^{\circ} 44.0^{\prime} \mathrm{E}$ ) for both field and laboratory experiments. Experiments were carried out between February and April 2008 when primary production and epiphytic biomass are high (Paling \& McComb 2000).

Upon collection, macrophytes and gastropods were kept in seawater and transported to laboratory aquaria. All aquaria were aerated using air stones, housed in a laboratory at $19^{\circ} \mathrm{C}$ room temperature, and illuminated with $36 \mathrm{~W}$ Sylvania daylight fluorescent lights providing ca. $40 \mu \mathrm{mol} \mathrm{m}^{-2} \mathrm{~s}^{-1}$ on a $12 / 12 \mathrm{~h}$ day/night cycle prior to experimentation.

\section{Enrichment procedure of kelp}

Kelp was enriched with ${ }^{15} \mathrm{~N}$ using ${ }^{15} \mathrm{NH}_{4} \mathrm{Cl}_{2}(98 \%$, Aldrich catalogue number 414-273-3850) following methods adapted from Boschker et al. (2000). We added $35 \mathrm{mg}$ of ${ }^{15} \mathrm{NH}_{4} \mathrm{Cl}_{2}$ dissolved in milli-Q-water to $30 \mathrm{l}$ of seawater. About $600 \mathrm{~g}$ of Ecklonia radiata, including stipe, was cleaned of epiphytes using a soft brush and placed in aquaria for $48 \mathrm{~h}$ under natural light conditions. The mean $( \pm \mathrm{SE})$ nitrogen stable isotope ratio $\left(\delta^{15} \mathrm{~N}\right)$ of labelled kelp was $1907 \pm 221 \%$ (n = 5) while unlabelled kelp had values of $4.86 \pm$ $0.29 \%$. $\delta$ values are not accurate at the high levels shown for labelled kelp (Fry 2006) and are provided here as approximate levels only. Although the enrichment of ${ }^{15} \mathrm{~N}$ was high, the mean percent $\mathrm{N}$ was not altered ( $t$-observed $=-0.376 ; t$-critical $=2.391 ; \mathrm{p}>$ $0.05)$ between the treatment $(0.85 \pm 0.09)$ and control $(0.89 \pm 0.06)$ kelp.

\section{Uptake of kelp-derived nitrogen by seagrass and algae}

Both laboratory and field experiments were used to test the uptake of nitrogen from Ecklonia radiata by seagrass and epiphytes. The laboratory experiment comprised treatments of labelled kelp placed with either (1) clean seagrass shoots with no epiphytes or rhizomes to test for the uptake of $\mathrm{N}$ by seagrass leaves, (2) clean seagrass shoots with no epiphytes but with rhizomes to test for uptake through leaves and rhizomes, or (3) seagrass shoots with epiphytes but without rhizomes to test for uptake by epiphytes. Three controls were set up to match the above treatments but without labelled kelp. Five replicates were established for each treatment and control. For the 'clean seagrass' treatments and controls, seagrass shoots containing minimal epiphytic growth were selected and then lightly scraped with a razor to remove any potential fouling, whereas seagrass shoots with relatively high levels of epiphytic growth were selected for the other treatments and controls.

Approximately $2.5 \mathrm{~g}$ (blotted wet $\mathrm{wt}$ ) of seagrass with epiphytes and $\sim 2.5 \mathrm{~g}$ (blotted wet wt) of seagrass without epiphytes were placed in $770 \mathrm{ml}$ plastic containers in aerated seawater, to which $\sim 2.5 \mathrm{~g}$ (blotted wet wt) of labelled kelp thallus was added to each treatment aquarium. Here and in other aquaria experiments, aquaria were maintained at $19^{\circ} \mathrm{C}$ using the luminance previously described. After $96 \mathrm{~h}$, seagrass and epiphyte samples were removed, thoroughly rinsed in filtered seawater and processed for $\delta^{15} \mathrm{~N}$ determination (see 'Isotope analyses' below). Seagrass leaves were scraped and processed separately from the epiphytes.

A 2-way ANOVA was used to test for differences in $\delta^{15} \mathrm{~N}$ among treatments and primary producers. Here, and in subsequent analyses, all factors were considered as fixed factors, and the data were natural log-transformed prior to analysis to meet the requirements of homogeneity of variance and normality according to the Levene's and Kolmogorov-Smirnov tests. Furthermore, where a significant $(p<0.05)$ difference occurred, post hoc Tukey's HSD tests were used to distinguish between groups.

To test for the uptake of kelp-derived ${ }^{15} \mathrm{~N}$ in a field setting, a treatment using labelled kelp was established in a Posidonia sinuosa seagrass meadow, along with the control that lacked labelled kelp. The levels of ${ }^{15} \mathrm{~N}$ in the surrounding seagrasses and epiphytic algae were determined. To test for any effect of time on the release of dissolved $\mathrm{N}$ from decaying kelp, the $\delta^{15} \mathrm{~N}$ values of seagrass or algae adjacent to the treatments were measured after 2 and 4 wk. Each of the 5 replicate treatments for each time comprised $300 \mathrm{~g}$ wet wt of labelled kelp, which were placed in nylon mesh-net bags and pegged randomly throughout the meadow for collection after 2 and $4 \mathrm{wk}$. The set up and procedure for all replicates for the control 
were identical to those of the treatment, except they lacked labelled kelp. Treatment and control replicates were placed $\geq 5 \mathrm{~m}$ apart to avoid cross contamination of treatments and controls. At each time, approximately 5 seagrass leaves and associated epiphytes immediately adjacent to the mesh bags were collected, placed in plastic bags on ice, and then frozen prior to processing. Samples were defrosted and the epiphytes scraped from the control and treatment shoots and processed for $\delta^{15} \mathrm{~N}$ analyses (see 'Isotope analyses' below). A 3-way ANOVA was conducted to test for differences in $\delta^{15} \mathrm{~N}$ values between plant types (seagrass leaves vs epiphytes), treatments and times.

\section{Assimilation of nitrogen by gastropods}

Both laboratory and field experiments were used to determine whether nitrogen from Ecklonia radiata was assimilated by the gastropod Cantharidus lepidus during late February and March 2008. Laboratory experiments tested whether kelp was consumed by $C$. lepidus in the presence or absence of alternative (autochthonous) food sources. Four treatments were established: (1) Posidonia sinuosa leaves and associated epiphytes with labelled kelp, (2) $P$. sinuosa leaves without epiphytes but with labelled kelp, (3) labelled kelp only, and (4) seagrass only. Controls contained gastropods and $P$. sinuosa with epiphytes but no kelp. To dilute ${ }^{15} \mathrm{~N}$-enriched nutrients being released into the water and thus minimise the indirect uptake of ${ }^{15} \mathrm{~N}$ through the consumption of ${ }^{15} \mathrm{~N}$ enriched seagrass or epiphytes, or through diffusion from the water, experimental units with large mesh panels were placed in a large, flow-through reservoir system. Prior to the experiments, gastropods had algal growth scraped from their shells and were kept for $5 \mathrm{~d}$ in aquaria that contained a mixture of macrophytes. Gastropods were then transferred to experimental units in the flow-through system where they were starved for $48 \mathrm{~h}$ prior to the addition of food resources at the start of the experiment.

Each experimental unit contained $\sim 3 \mathrm{~g}$ (blotted wet wt) of each macrophyte and 5 Cantharidus lepidus individuals, with 5 replicates established for each treatment. Posidonia sinuosa leaves with and without epiphytes were selected and processed as above. The experiment was maintained for $96 \mathrm{~h}$ under natural, but filtered, light conditions, and at ambient sea temperature $\left(18\right.$ to $20^{\circ} \mathrm{C}$ ) for the time of the year. On termination, samples of gastropods and the macrophytes on which they were fed were processed for stable istope analyses. Where epiphytes were present on seagrass leaves, they were scraped using a razor blade. Samples of seagrass and/or epiphytes and samples of kelp from the kelp-only treatment were then thoroughly rinsed in clean seawater and processed for $\delta^{15} \mathrm{~N}$ analyses. Foot muscle tissue was removed from the gastropods and processed for $\delta^{15} \mathrm{~N}$ analyses. A 1-way ANOVA was used to test for differences in $\delta^{15} \mathrm{~N}$ among control and treatments.

To characterise the densities of gastropods at the study site, gastropods were counted in 5 randomly placed $0.25 \times 0.25 \mathrm{~m}$ quadrats throughout the seagrass meadow. Cantharidus lepidus was by far the dominant gastropod grazer in the seagrass meadow, where it was present at an average density of $310 \pm$ 106 ind. $\mathrm{m}^{-2}$. The shell width of this species ranged from 6 to $10 \mathrm{~mm}$ and the fresh biomass ranged between 15 and $89 \mathrm{mg}$.

To test for the uptake of kelp-derived ${ }^{15} \mathrm{~N}$ by Cantharidus lepidus in the field setting, labelled kelp was placed in a Posidonia sinuosa seagrass meadow. Treatments consisting of $300 \mathrm{~g}$ (blotted wet wt) of labelled kelp were tethered to steel pegs and placed randomly into $P$. sinuosa seagrass meadows. Ten replicate treatment thalli were placed out at Time 0 spaced $\geq 5 \mathrm{~m}$ from each other to avoid isotope contamination. Samples of C. lepidus (5 individuals in each) were collected from the meadow at Time 0 (immediately prior to deployment of labelled kelp), 1 (after $1 \mathrm{wk}$ ) and 2 (after $2 \mathrm{wk}$ ) to determine $\delta^{15} \mathrm{~N}$ values. The Time 0 samples (controls) were collected from 5 randomly selected locations. At Time 1 and 2, 5 to 10 gastropods were collected from an area within $0.5 \mathrm{~m}$ of the tethered kelp for each replicate. At Time 1, kelp was replaced with fresh, labelled kelp to ensure a continued supply of label in treatments. Gastropod samples were processed for $\delta^{15} \mathrm{~N}$ analyses and a 1-way ANOVA was used to test for differences in $\delta^{15} \mathrm{~N}$ of gastropods between times.

\section{Isotope analyses}

For stable isotope analyses, all seagrass, algae and gastropod samples were dried for $48 \mathrm{~h}$ at $60^{\circ} \mathrm{C}$ and ground to a fine powder. Due to the small size of gastropods, 5 individuals were pooled per replicate sample for both laboratory and field experiments. The dried and weighed samples of gastropods (2 $\mathrm{mg})$ and plant material (5 mg) were combusted by elemental analyser (ANCA-GSL, Europa) to $\mathrm{N}_{2}$ at Edith Cowan University, Australia, and subsequently purified by gas chromatography. The nitrogen elemental compo- 
sition and isotope ratios were then determined by continuous flow isotope ratio mass spectrometry (2020 IRMS, Europa). Since our aim was to determine the uptake of kelp-derived $\mathrm{N}$, rather than to determine a mass balance, we measured $\delta^{15} \mathrm{~N}$ of the plant and animal samples. These samples were compared to plant and fish laboratory standards respectively that had been previously calibrated against standard International Atomic Energy Agency (IAEA) or National Institute of Standards and Technology (NIST) reference materials with a precision of $<0.1 \%$. For further details of the analytical procedures, see Crawley et al. (2009).

\section{Kelp leachate characterisation}

In order to characterise the types of $\mathrm{N}$ that could be available to seagrasses and epiphytes in proximity to allochthonous kelp, we established an experiment to measure total dissolved organic nitrogen (DON), dissolved inorganic nitrogen (DIN) and a range of $\mathrm{N}$ compounds derived directly or indirectly from fresh and 'aged' Ecklonia radiata. Kelp thalli were aged by placing them in 5 mesh bags next to the reef for $2 \mathrm{wk}$, which represented the time that kelp can typically persist in detached form within seagrass meadows (G. A. Hyndes pers. obs.). Five samples of fresh kelp thalli were also collected when the aged kelp was retrieved. Two of the 5 bags of aged kelp could not be located at the time of collection, leaving 3 replicate samples for further analyses.

In the laboratory, $\sim 300 \mathrm{~g}$ of clean kelp for each of the fresh and aged replicate samples were placed in separate aquaria containing $6 \mathrm{l}$ of aerated artificial seawater. An additional aquarium was set up with the same seawater but containing no kelp, to collect a reference sample for nutrient levels that were not associated with the kelp. The aquaria were placed in the laboratory in ambient light and temperature conditions. After $24 \mathrm{~h}$, approximately $1 \mathrm{l}$ of leachate was sampled from each replicate. Filtered (0.45 $\mu \mathrm{m}$ GMF) samples were analysed for DON, $\mathrm{NO}_{2+3}-\mathrm{N}$ and $\mathrm{NH}_{4}-$ $\mathrm{N}$ using standard methods 4500-NO3-F (cadmiumreduction) and 4500-NH3-H (phenate) on a SKALAR autoanalyser. Since urea has been shown to be a small molecular weight $\mathrm{N}$-compound that can be taken up by seagrass and algae (Vonk et al. 2008), we also analysed samples for this compound using the methods of Mulvenna \& Savidge (1992). Nutrient concentrations were calculated by subtracting the level detected in the reference sample. If values were negative, data were set to zero, as these negative val- ues are likely to relate to microbial processes or uptake by kelp. Data were standardized as a rate of leaching per $100 \mathrm{~g}$ wet wt kelp per day.

\section{RESULTS}

\section{Uptake of nitrogen by seagrass and algae}

In the laboratory experiment, seagrass and epiphytes incubated with ${ }^{15} \mathrm{~N}$-enriched kelp had higher $\delta^{15} \mathrm{~N}$ values than the comparable control material (Fig. 1), which resulted in a significant treatment effect $(\mathrm{p}<0.001$; Table 1$) . \delta^{15} \mathrm{~N}$ values were higher in epiphytes than in seagrass leaves that were either attached or not attached to rhizomes during the

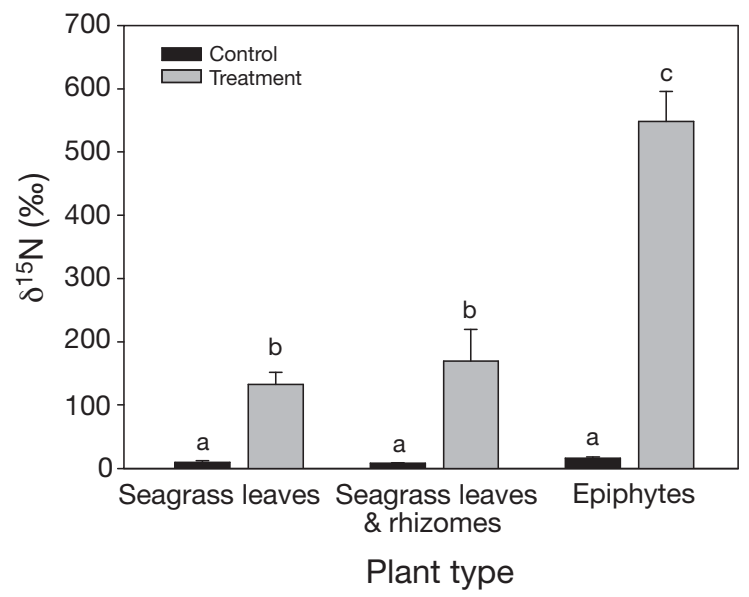

Fig. 1. Posidonia sinuosa. Mean (+SE) nitrogen staple isotope $\left(\delta^{15} \mathrm{~N}\right)$ values of different plant types incubated in the laboratory with unlabelled (control) and ${ }^{15} \mathrm{~N}$-labelled (treatment) Ecklonia radiata kelp. Shared letters indicate no significant difference $(p \geq 0.05)$

Table 1. Posidonia sinuosa. Results of 2-way ANOVA testing for differences in the nitrogen stable isotope $\left(\delta^{15} \mathrm{~N}\right)$ values of different combinations of primary producers (plant types: Posidonia sinuosa seagrass leaves, seagrass leaves with rhizomes still attached, and seagrass leaves with epiphytes) in different treatments (unenriched or ${ }^{15} \mathrm{~N}$-enriched Ecklonia radiata kelp) in aquaria experiments. Data were natural logtransformed prior to analysis to meet requirements of homogeneity using the Levene's test. Significant values in bold

\begin{tabular}{|lccr|}
\hline Factor & df & MS & \multicolumn{1}{c|}{ p } \\
\hline Treatment & 1 & 69.9 & $<\mathbf{0 . 0 0 1}$ \\
Plant type & 2 & 3.34 & $<\mathbf{0 . 0 0 1}$ \\
Treatment $\times$ Plant type & 2 & 0.52 & 0.058 \\
Error & 24 & 0.16 & \\
\hline
\end{tabular}




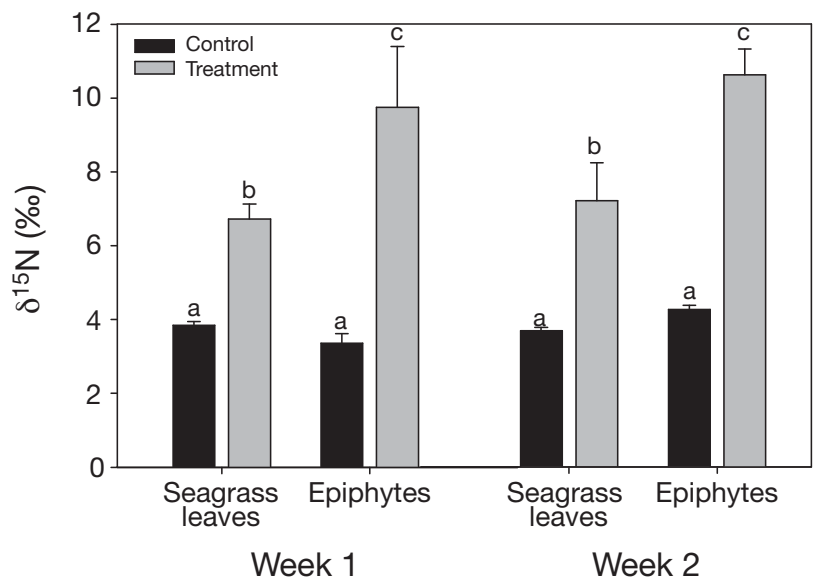

Fig. 2. Posidonia sinuosa. Mean (+SE) nitrogen staple isotope $\left(\delta^{15} \mathrm{~N}\right)$ values of seagrass leaves only and leaves containing epiphytes after $2 \mathrm{wk}$ in seagrass plots that contained unlabelled (control) or ${ }^{15} \mathrm{~N}$-labelled Ecklonia radiata kelp. Shared letters indicate no significant difference $(p \geq 0.05)$

Table 2. Posidonia sinuosa. Results of 3-way ANOVA testing for differences in the nitrogen stable isotope $\left(\delta^{15} \mathrm{~N}\right)$ values of different primary producers (plant types: Posidonia sinuosa leaves and seagrass periphyton) in different treatments (unlabelled or ${ }^{15} \mathrm{~N}$-labelled Ecklonia radiata kelp) left in the field at different times ( 1 and $2 \mathrm{wk}$ ). Data were natural logtransformed prior to analysis but still did not meet requirements of homogeneity using the Levene's test $(F=2.412, \mathrm{p}=$ 0.042). As a result, alpha was set at 0.01 (McGuinness 2002). Significant values in bold

\begin{tabular}{|lccr|}
\hline Factors & df & MS & \multicolumn{1}{c|}{$\mathrm{p}$} \\
\hline Treatment & 1 & 6.09 & $<\mathbf{0 . 0 0 1}$ \\
Plant type & 1 & 0.35 & $\mathbf{0 . 0 0 4}$ \\
Time & 1 & 0.09 & 0.126 \\
Treatment $\times$ Plant type & 1 & 0.35 & $\mathbf{0 . 0 0 3}$ \\
Treatment $\times$ Time & 1 & 0.00 & 0.849 \\
Plant Type $\times$ Time & 1 & 0.09 & 0.120 \\
Treatment $\times$ Plant type $\times$ Time & 1 & 0.03 & 0.393 \\
Error & 32 & 0.04 & \\
& & & \\
\hline
\end{tabular}

experiment (Fig. 1), resulting in a plant type effect $(p<0.001$; Table 1$)$. The $\delta^{15} \mathrm{~N}$ values of seagrass or epiphytes in the controls did not differ.

In the field experiment, $\delta^{15} \mathrm{~N}$ values of seagrass and epiphytes were higher in areas where labelled kelp had been placed in the seagrass meadows than those in control areas (Fig. 2). This was observed at both 2 and $4 \mathrm{wk}$ after initiation of the experiment. ANOVA results confirmed a significant treatment effect $(\mathrm{p}<$ 0.001 ; Table 2) in both seagrass and epiphytes. However, $\delta^{15} \mathrm{~N}$ was higher in epiphytes than seagrass located next to ${ }^{15} \mathrm{~N}$-enriched kelp, resulting in a plant type by treatment interaction $(\mathrm{p}=0.003$; Table 2$)$.

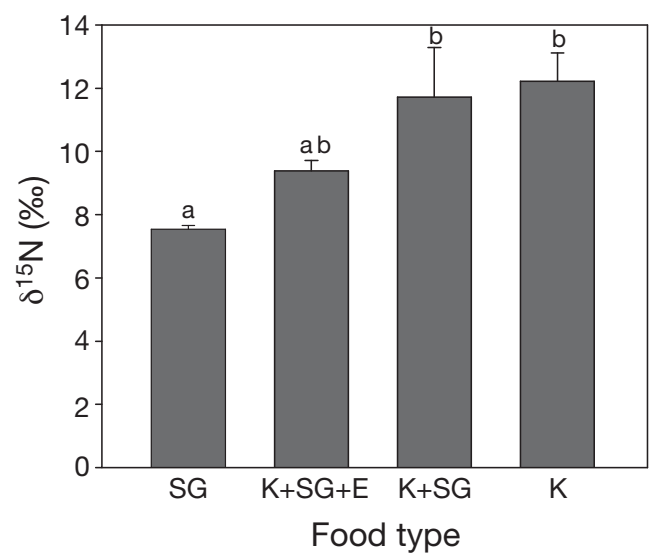

Fig. 3. Cantharidus lepidus. Mean (+SE) nitrogen staple isotope $\left(\delta^{15} \mathrm{~N}\right)$ values of gastropods after $96 \mathrm{~h}$ in aquaria with different food sources: Posidonia sinuosa seagrass leaves with epiphytes (SG) ${ }_{i}^{15} \mathrm{~N}$-labelled Ecklonia radiata kelp and seagrass with epiphytes $(\mathrm{K}+\mathrm{SG}+\mathrm{E}) ;{ }^{15} \mathrm{~N}$-labelled kelp and seagrass with no epiphytes $(\mathrm{K}+\mathrm{SG})$, and ${ }^{15} \mathrm{~N}$-labelled kelp only $(K)$. Shared letters indicate no significant difference $(p \geq 0.05)$

\section{Assimilation of nitrogen by a mesograzer}

In the laboratory trials, $\delta^{15} \mathrm{~N}$ values of the gastropod Cantharidus lepidus differed depending on the food source (ANOVA: $\mathrm{MS}=23.49$, $\mathrm{df}=3, \mathrm{p}=0.008$ ), with the lowest values in animals provided with seagrass alone and highest in those provided with labelled kelp alone or seagrass leaves and labelled kelp (Fig. 3). Those gastropods provided with combined seagrass leaves, epiphytes and labelled kelp exhibited intermediate values of $\delta^{15} \mathrm{~N}$ that did not differ significantly from the other treatments. In the field experiment, $\delta^{15} \mathrm{~N}$ values of gastropods collected from the meadow surrounding ${ }^{15} \mathrm{~N}$-labelled kelp increased over time (ANOVA: $\mathrm{MS}=3.77, \mathrm{df}=2, \mathrm{p}=$ 0.042). $\delta^{15} \mathrm{~N}$ increased significantly from $2.4 \%$ at Time 0 to $16.7 \%$ after $2 \mathrm{wk}$ (i.e. at Time 2), while $\delta^{15} \mathrm{~N}$ $(20.0 \pm 15.0 \%)$ after only 1 wk did not differ significantly from the earlier or later times (Fig. 4).

\section{Leachate concentrations from aged Ecklonia}

After $24 \mathrm{~h}$, seawater with fresh kelp was highly enriched with DON (mean \pm SE: $1224.8 \pm 344.8 \mu \mathrm{g} \mathrm{N}$ $\left(100 \mathrm{~g} \mathrm{kelp}^{-1} \mathrm{~d}^{-1}\right)$ as well as $\mathrm{NH}_{4}-\mathrm{N}(27.6 \pm 29.7 \mu \mathrm{g} \mathrm{N}$ $\left(100 \mathrm{~g} \mathrm{kelp}^{-1} \mathrm{~d}^{-1}\right)$, but concentrations of $\mathrm{NO}_{\mathrm{x}}-\mathrm{N}$ were below detectable levels. Seawater with fresh kelp contained $67.3 \pm 7.8 \mu \mathrm{g}$ urea $(100 \mathrm{~g} \mathrm{kelp})^{-1} \mathrm{~d}^{-1}$. The amount of DON and urea in water containing kelp aged for $2 \mathrm{wk}(736.5 \pm 209.1$ and $36.9 \pm 0.4 \mu \mathrm{g} \mathrm{N}(100 \mathrm{~g}$ kelp $)^{-1} \mathrm{~d}^{-1}$, respectively) was almost half that of water 


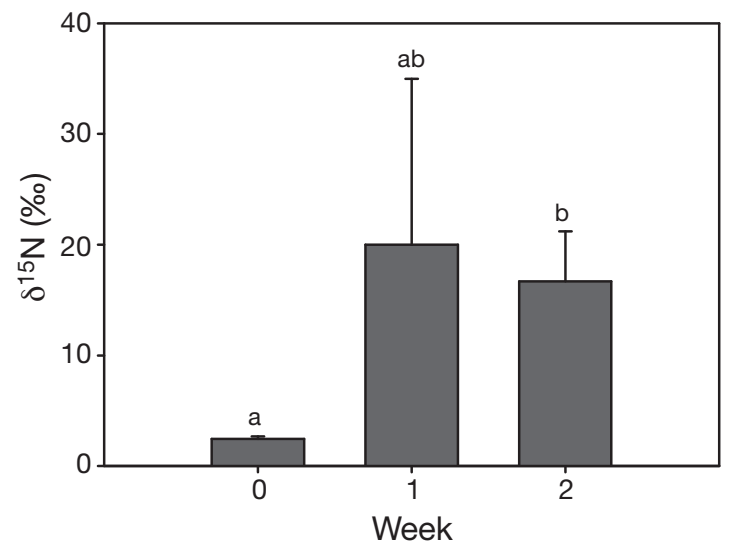

Fig. 4. Cantharidus lepidus. Mean $( \pm \mathrm{SE}, \mathrm{n}=5)$ nitrogen staple isotope $\left(\delta^{15} \mathrm{~N}\right)$ values of gastropods collected from locations in a Posidonia sinuosa seagrass meadow that contained ${ }^{15} \mathrm{~N}$-enriched Ecklonia radiata kelp at Time 0 and after 1 and $2 \mathrm{wk}$. Shared letters indicate no significant difference $(\mathrm{p} \geq 0.05)$

with fresh kelp. The amount of $\mathrm{NH}_{4}$ was almost negligible after this period of aging $(2.0 \pm 1.8 \mu \mathrm{g} \mathrm{N}(100 \mathrm{~g}$ kelp) ${ }^{-1} d^{-1}$ ).

\section{DISCUSSION}

The dominance of kelp on subtidal, temperate reefs (Dayton 1985) and the large quantities that are removed from those reefs (Hobday 2000) provides a potential vector for subsidising productivity across ecosystems. We clearly demonstrated through the enrichment of ${ }^{15} \mathrm{~N}$ in the kelp Ecklonia radiata that kelp-derived nitrogen can be assimilated by seagrass and its epiphytes, as well as by mesograzers in seagrass meadows. Thus, despite seagrass ecosystems being characterised by high levels of in situ primary production and resource availability (Borowitzka et al. 2006, Romero et al. 2006), we demonstrate clear pathways for kelp to subsidise these systems. In their meta-analysis, Marczak et al. (2007) concluded that, while the strength of subsidies is not related to in situ productivity of the recipient system, it is negatively related to the level of ambient resources. Although our study does not test for the effectiveness of subsidies, we demonstrate a dual pathway for potential subsidies by kelp that could provide a role in ecosystem function.

\section{Subsidy pathway to primary producers}

We have provided clear evidence of the uptake of nitrogen from kelp by seagrass and its epiphytic algae within days of the addition of allochthonous kelp. For seagrasses, DIN has typically been considered to be the primary nitrogen source for uptake (Romero et al. 2006). In particular, uptake rates of $\mathrm{NH}_{4}$ are rapid in seagrass leaves and roots (Vonk et al. 2008). Furthermore, while there is no evidence that seagrasses are N-limited, concentrations of DIN can be low in seagrass meadows (e.g. McGlathery et al. 2001), which is apparent in our study region. Although sediments of seagrass meadows in the region contain about $60 \mathrm{~g} \mathrm{~N} \mathrm{~m}^{-2}$ (Cambridge \& Hocking 1997), DIN is generally very low $\left(<200 \mu \mathrm{g} \mathrm{l}^{-1}\right.$ in sediment porewaters and $<20 \mu \mathrm{g} \mathrm{l}^{-1}$ in the canopy; P. Lavery unpubl. data). While we did not directly measure DIN being leached from kelp in our experiment, kelp appears to contribute little to the small DIN pool available to seagrasses. Such low levels could be explained either through (1) very little DIN being leached from kelp, (2) leaked DIN being taken up again by the kelp or (3) leaked DIN being rapidly transformed to particulate or DON through bacterial processes. On beaches, kelp has been shown to decompose rapidly, resulting in large quantities of nutrients being leached and microbes colonising kelp wrack (see Colombini \& Chelazi 2003). The importance of microbes in this degradation process is highlighted by early studies on beach wrack showing that $\sim 90 \%$ of leachate from kelp is utilised by microbes (Koops et al. 1982), which can account for nearly $90 \%$ of the annual beach productivity (Koop \& Griffiths 1982).

Whether through direct leaching or microbial processes, DON formed the bulk of kelp-derived $\mathrm{N}$ available to surrounding seagrasses and epiphytes. DON concentrations can be high in seagrass meadows of the region, ranging from about 100 to $1000 \mu \mathrm{g}$ $\mathrm{l}^{-1}$ in the sediment porewater and 125 to $340 \mathrm{\mu g} \mathrm{l}^{-1}$ in the seagrass canopy (P. Lavery unpubl. data). Our data suggest that DON supplied directly or indirectly from kelp could contribute substantially to those levels. Recent evidence suggests that DON plays a greater role in seagrass productivity than previously thought. Small molecular weight DON compounds (e.g. amino acids and urea) can be taken up by seagrasses through their leaves and/or roots and by algae (Vonk et al. 2008). We did not examine the suite of amino acids in the kelp-derived DON but did detect urea. While kelp itself is unlikely to release urea, microbial communities are likely to catabolise larger $\mathrm{N}$ compounds to urea (Berg \& Jørgensen 2006). The ability of leaves to uptake DON derived directly or indirectly from kelp provides seagrass with a shortcut to bioavailable $\mathrm{N}$ directly from the 
water column, though DON could also enter the sedimentary N pool.

Regardless of the form of $\mathrm{N}$, the elevated $\delta^{15} \mathrm{~N}$ in seagrass from the field indicates that kelp-derived $\mathrm{N}$ is assimilated by seagrass. The lack of a difference in $\delta^{15} \mathrm{~N}$ between seagrass leaves only and those with rhizome and roots in our experiment suggests that $\mathrm{N}$ can be taken up through both leaves and roots, which is supported by Vonk et al. (2008) who demonstrated that both DIN and DON are taken up by seagrass leaves and roots. However, the far higher $\delta^{15} \mathrm{~N}$ in epiphytes compared to that in seagrass leaves suggests that the uptake rate of $\mathrm{N}$ by algae is greater. Despite the high biomass of kelp that dislodges from temperate reefs throughout the world (see Orr et al. 2005) and the high decomposition rates of brown algae (Pedersen et al. 2005), surprisingly little work has been carried out on the amounts and types of nutrients being released from allochthonous kelp. Lourey \& Kirkman (2009) suggested that the higher levels of DIN in the water column during winter in the study region could be related to the kelp dislodged from the reefs. Furthermore, Kirkman \& Kendrick's (1997) estimates of detached kelp biomass produced in the region per year (1270 to $7800 \mathrm{t}$ dry wt $\mathrm{km}^{-2}$ ) indicates that considerable amounts would pass through seagrass meadows, resulting in significant amounts of nutrients being released into sea- grass meadows. Indeed, Wernberg et al. (2006) recorded an average of $330 \mathrm{~g} \mathrm{FW}$ (fresh weight) $\mathrm{m}^{-2}$ of kelp wrack in seagrass meadows in the region during one time of the year. Thus, kelp-derived $\mathrm{N}$ could provide an alternative, allochthonous source of $\mathrm{N}$ to recycled autochthonous sources in the seagrass ecosystem.

The ecological significance of the nutrients provided by kelp remains to be determined. Cambridge \& Hocking (1997) argue that external nutrient subsidies are necessary to balance the loss of $\mathrm{N}$ by leaf export and proposed a detrital pathway and sedimentary burial of organic matter as providing this external subsidy. The large export of seagrass leaves and thus nutrients from seagrass systems (Mateo et al. 2006, Heck et al. 2008) suggests that external sources of nutrients could be particularly important for seagrass systems. Kelp could well contribute significantly to that detrital pathway, though our results clearly indicate that this could also be affected through degradation of surficial kelp and not only a sedimentary pathway (Fig. 5). Our data also show that seagrasses and consumers do access this material despite other resources being available. Also, recent unpublished work (T. de Bettignies, P. Lavery \& T. Wernberg) suggests that kelp dislodgment during winter storms is a minor contributor of kelp to adjacent ecosystems, while erosion of tip material is more

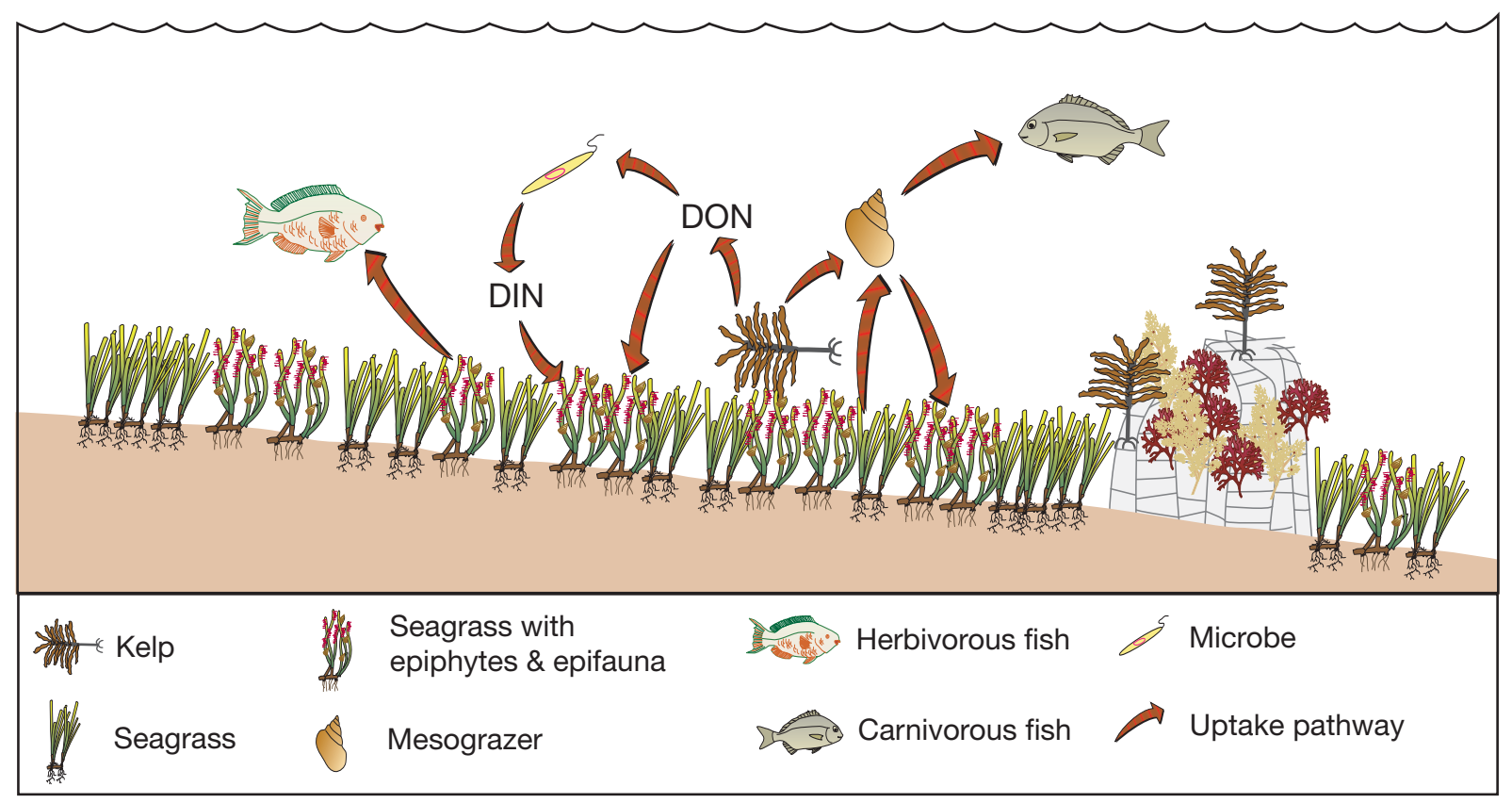

Fig. 5. Pathways of nitrogen uptake from detached kelp in a seagrass ecosystem. DIN: dissolved inorganic nitrogen; DON: dissolved organic nitrogen 
substantial and occurs throughout the year. Therefore, expecting kelp-derived $\mathrm{N}$ inputs throughout the year, not just during autumn and winter when seagrass growth rates are slowest, is reasonable. Thus, there is the potential for the significance of kelp detritus to vary throughout the year as a function of the supply rate, the supply of alternative $\mathrm{N}$ resources, and the demand of the recipient ecosystem. Future work should address not only the effectiveness of the trophic subsidy provided by kelp wrack but also the intra-annual variability in any subsidy.

\section{Subsidy pathway to mesograzer consumers}

Mesograzers are an important component of seagrass ecosystems, and any increases in primary production, particularly epiphytes, resulting from kelp subsidies would increase food availability for a range of mesograzers in these ecosystems. Our study has shown that a dominant mesograzer in seagrass meadows of the region, Cantharidus lepidus, assimilated $\mathrm{N}$ from kelp. An earlier stable isotope study by Smit et al. (2006) suggested that macroalgae were a prominent part of the diet of this species in seagrass meadows, but they were unable to distinguish the role of autochthonous and allocthonous resources. However, since this species has been shown experimentally to consume kelp (Doropoulos et al. 2009), the increase in $\delta^{15} \mathrm{~N}$ almost certainly reflects assimilation of $\mathrm{N}$ derived directly or indirectly from kelp. Indeed, gastropods were observed feeding and leaving clear grazing marks on kelp during both the laboratory and field experiments of this study and during laboratory experiments by Doropoulos et al. (2009). However, since C. lepidus exhibits no clear preference for kelp or the typically abundant epiphytic algae (Doropoulos et al. 2009), the elevated $\delta^{15} \mathrm{~N}$ values of $C$. lepidus could also reflect an indirect pathway through grazing on epiphytic algae that have assimilated $\mathrm{N}$ from drifting kelp (Fig. 5). Gastropods were observed on kelp throughout the field experiment, but the reduced variability in $\delta^{15} \mathrm{~N}$ after $2 \mathrm{wk}$ indicates that broader incorporation into the food web via grazing may require kelp to remain in the meadow for periods $\geq 2 \mathrm{wk}$. Although food preferences are variable among species of amphipods (Cruz-Rivera \& Hay 2000, Taylor \& Steinberg 2005), some of these mesograzers exhibit strong preferences for brown algae in a range of nearshore habitats, such as reefs and surf zones (Duffy \& Hay 2000, Pennings et al. 2000, Crawley \& Hyndes 2007). Furthermore, kelp provides an important food source as drift material for mesograzers on intertidal and subtidal reefs (Bustamante et al. 1995, Vanderklift et al. 2005) and as particulate and/or dissolved organics for filter and suspension feeders (Stuart et al. 1982, Duggins et al. 1989). A plausible explanation could therefore be that a range of consumers could also contribute to the uptake of nitrogen from kelp in seagrass meadows. The presence of high ambient food resources in seagrass meadows (Borowitzka et al. 2006) suggests that unlike aquatic ecosystems with little in situ productivity, such as shoreline systems (Bustamante et al. 1995) and rivers (Wallace et al. 1999), mesograzer populations in seagrass meadows are unlikely to depend solely on allochthonous resources. However, food resources have been shown to be limiting in local seagrass systems at certain times of the year (Edgar 1990). Thus, the input of alternative food resources such as reef-derived kelp has the potential to enhance their population sizes, and the importance of this subsidy is likely to increase when ambient resources (e.g. epiphytes) are low.

\section{CONCLUSIONS}

Our study has shown 2 clear pathways in which the movement of allochthonous resources across ecosystem boundaries may influence productivity in a highly productive macrophyte system through (1) the uptake of nutrients directly by seagrass and associated epiphytes and (2) direct grazing by abundant mesograzers (Fig. 5). This result contrasts with the vast majority of studies to date, which have focused on crossboundary movement of donor material to ecosystems exhibiting little or no in situ primary production, such as forests to rivers (Wallace et al. 1999), forests to fjords (McLeod \& Wing 2007), and ocean to arid island (Polis et al. 1997). The importance of allochthonous kelp as a subsidy has been shown for intertidal (Bustamante et al. 1995) and surf (Crawley et al. 2009) zones and has been shown to be utilised by reefdwelling urchins despite the availability of autochthonous kelp (Vanderklift \& Wernberg 2008). The large quantities of detached brown algae, particularly kelp, along coasts worldwide suggests that this allochthonous resource could contribute to food webs in a range of ecosystems. This allochthonous resource may occur in pulses as it is dislodged from reefs, similar to Macrocystis pyrifera in California (Hobday 2000). However, unlike M. pyrifera that has pnuematocysts to provide positive buoyancy, Ecklonia radiata is neutrally to negatively buoyant. Thus, while nutri- 
ents from $M$. pyrifera will be available to both pelagic and benthic ecosystems once detached from reefs (Hobday 2000), E. radiata would provide nutrients predominantly to benthic primary producers and consumers as it is transported away from reefs.

Acknowledgements. We thank P. Kiss, R. Czarnik and K. Inostrova for their help with the field and laboratory experiments, as well as J. Tranter, M. Bannister and S. Wang for the chemical analyses. Thanks also to $\mathrm{M}$. Boyce, P. Moore and $\mathrm{T}$. Wernberg for their helpful discussions or constructive comments on the manuscript. Financial support was provided by Government of Western Australia through the Strategic Research Fund for the Marine Environment. This study was carried out under the permit requirements for working on invertebrates and in marine parks of Western Australia.

\section{LITERATURE CITED}

Baxter CV, Fausch KD, Murakami M, Chapman PL (2004) Fish invasion restructures stream and forest food webs by interrupting reciprocal prey subsidies. Ecology 85: 2656-2663

Berg GM, Jørgensen NOG (2006) Purine and pyrimidine metabolism by estuarine bacteria. Aquat Microb Ecol 42: 215-226

Borowitzka MA, Lavery PS, van Keulen M (2006) Epiphytes of seagrasses. In: Larkum AWD, Orth RJ, Duarte CM (eds) Seagrasses: biology, ecology and conservation. Springer, Dordrecht, p 441-461

- Boschker HTS, Wielemaker A, Schaub BEM, Holmer M (2000) Limited coupling of macrophyte production and bacterial carbon cycling in the sediments of Zostera spp. meadows. Mar Ecol Prog Ser 203:181-189

Bustamante RH, Branch GM, Eekhout S (1995) Maintenance of an exceptional intertidal grazer biomass in South Africa: subsidy by subtidal kelps. Ecology 76:2314-2329

Cambridge ML, Hocking PJ (1997) Annual primary production and nutrient dynamics of the seagrasses Posidonia sinuosa and Posidonia australis in south-western Australia. Aquat Bot 59:277-295

Colombini I, Chelazzi L (2003) Influence of marine allochthonous input on sandy beach communities. Oceanogr Mar Biol Annu Rev 41:115-159

Crawley KR, Hyndes GA (2007) The role of different types of detached macrophytes in the food and habitat choice of a surf-zone inhabiting amphipod. Mar Biol 151:1433-1443

Crawley KR, Hyndes GA, Ayvazian SG (2006) Influence of different volumes and types of detached macrophytes on fish community structure in surf zones of sandy beaches. Mar Ecol Prog Ser 307:233-246

> Crawley KR, Hyndes GA, Vanderklift MA, Revill AT, Nichols PD (2009) Allochthonous brown algae are the primary food source for consumers in a temperate, coastal environment. Mar Ecol Prog Ser 376:33-44

> Cruz-Rivera E, Hay ME (2000) The effects of diet mixing on consumer fitness: macroalgae, epiphytes, and animal matter as food for marine amphipods. Oecologia 123: 252-264

> Dayton PK (1985) Ecology of kelp communities. Annu Rev Ecol Syst 16:215-245
Doropoulos C, Hyndes GA, Lavery PS, Tuya F (2009) Dietary preferences of two seagrass inhabiting gastropods: allochthonous vs autochthonous resources. Estuar Coast Shelf Sci 83:13-18

$>$ Duffy JE, Hay ME (2000) Strong impacts of grazing amphipods on the organization of a benthic community. Ecol Monogr 70:237-263

Duggins DO, Simenstad CA, Estes JA (1989) Magnification of secondary production by kelp detritus in coastal marine ecosystems. Science 245:170-173

Edgar GJ (1990) Population regulation, population dynamics and competition amongst mobile epifauna associated with seagrass. J Exp Mar Biol Ecol 144:205-234

Fry B (2006) Stable isotope ecology. Springer, New York, NY > Gende SM, Willson MF (2001) Passerine densities in riparian forests of southeast Alaska: potential effects of anadromous spawning salmon. Condor 103:624-629

Heck KL, Carruthers TJB, Duarte CM, Hughes AR, Kendrick G, Orth RJ, Williams SW (2008) Trophic transfers from seagrass meadows subsidize diverse marine and terrestrial consumers. Ecosystems 11:1198-1210

> Hobday AJ (2000) Abundance and dispersal of drifting kelp Macrocystis pyrifera rafts in the Southern California Bight. Mar Ecol Prog Ser 195:101-116

> Jernakoff P, Nielsen J (1997) The relative importance of amphipod and gastropod grazers in Posidonia sinuosa meadows. Aquat Bot 56:183-202

Kendrick GA, Lavery PS, Phillips JC (1999) Influence of Ecklonia radiata kelp canopy on structure of macro-algal assemblages in Marmion Lagoon, Western Australia. Hydrobiologia 398/399:275-283

Kirkman H (1984) Standing stock and production of Ecklonia radiata (C.Ag.): J. Agardh. J Exp Mar Biol Ecol 76: $119-130$

Kirkman H, Kendrick GA (1997) Ecological significance and commercial harvesting of drifting and beach-cast macroalgae and seagrasses in Australia: a review. J Appl Phycol 9:311-326

Kohzu A, Kato C, Iwata T, Kishi D, Murakami M, Nakano S, Wada E (2004) Stream food web fueled by methanederived carbon. Aquat Microb Ecol 36:189-194

Koop K, Griffiths CL (1982) The relative significance of bacteria, meio- and macrofauna on an exposed sandy beach. Mar Biol 66:295-300

> Koop K, Newell RC, Lucas MI (1982) Biodegradation and carbon flow based on kelp (Ecklonia maxima) debris in a sandy beach microcosm. Mar Ecol Prog Ser 7:315-326

> Lourey MJ, Kirkman H (2009) Short-lived dissolved nitrate pulses in a shallow Western Australian coastal lagoon. Mar Freshw Res 60:1068-1080

> Marczak LB, Thompson RM, Richardson JS (2007) Metaanalysis: trophic level, habitat, and productivity shape the food web effects of resource subsidies. Ecology 88: $140-148$

Mateo MA, Cebrián J, Dunton K, Mutchler T (2006) Carbon flux in seagrass ecosystems. In: Larkum AWD, Orth RJ, Duarte CM (eds) Seagrasses: biology, ecology and conservation. Springer, Dordrecht, p 159-192

McGlathery KJ, Berg P, Marino R (2001) Using porewater profiles to assess nutrient availability in seagrassvegetated carbonate sediments. Biogeochemistry 56: 239-263

> McGuinness KA (2002) Of rowing boats, ocean liners and tests of the ANOVA homogeneity of variance assumption. Austral Ecol 27:681-688 
McLeod RJ, Wing SR (2007) Hagfish in the New Zealand fjords are supported by chemoautotrophy of forest carbon. Ecology 88:809-816

Mellbrand K, Lavery P, Hyndes G, Hambäck P (2011) Linking land and sea: different pathways for marine subsidies. Ecosystems 14:732-744

Moore JC, Berlow EL, Coleman DC, de Ruiter PC and others (2004) Detritus, trophic dynamics and biodiversity. Ecol Lett 7:584-600

Mulvenna PF, Savidge G (1992) A modified manual method for the determination of urea in seawater using diacetylmonoxime reagent. Estuar Coast Shelf Sci 34:429-438

Orr M, Zimmer M, Jelinski DE, Mews M (2005) Wrack deposition on different beach types: spatial and temporal variation in the pattern of subsidy. Ecology 86:1496-1507

Orth RJ, Carruthers TJB, Dennison WC, Duarte CM and others (2006) A global crisis for seagrass ecosystems. Bioscience 56:987-996

Paling EI, McComb AJ (2000) Autumn biomass, belowground productivity, rhizome growth at bed edge and nitrogen content in seagrasses from Western Australia. Aquat Bot 67:207-219

Pedersen MF, Stæhr PA, Wernberg T, Thomsen MS (2005) Biomass dynamics of exotic Sargassum muticum and native Halidrys siliquosa in Limfjorden, Denmarkimplications of species replacements on turnover rates. Aquat Bot 83:31-47

Pennings SC, Carefoot TH, Zimmer M, Danko JP, Ziegler A (2000) Feeding preferences of supralittoral isopods and amphipods. Can J Zool 78:1918-1929

Polis GA, Anderson WB, Holt RD (1997) Toward an integration of landscape and food web ecology: the dynamics of spatially subsidized food webs. Annu Rev Ecol Syst 28: 289-316

Romero J, Lee KS, Pérez M, Mateo MA, Alcoverro T (2006) Nutrient dynamics in seagrass ecosystems. In: Larkum AWD, Orth RJ, Duarte CM (eds) Seagrasses: biology, ecology and conservation. Springer, Dordrecht, p $227-254$

Smit AJ, Brearley A, Hyndes GA, Lavery PS, Walker DI

Editorial responsibility: Catriona Hurd,

Dunedin, New Zealand
(2005) Carbon and nitrogen stable isotope analysis of an Amphibolis griffithii seagrass bed. Estuar Coast Shelf Sci 65:545-556

Smit AJ, Brearley A, Hyndes GA, Lavery PS, Walker DI (2006) ${ }^{15} \mathrm{~N}$ and ${ }^{13} \mathrm{C}$ analysis of a Posidonia sinuosa seagrass bed. Aquat Bot 84:277-282

Stuart VJ, Field G, Newell RC (1982) Evidence for absorption of kelp detritus by the ribbed mussel Aulacomya ater using a new ${ }^{51} \mathrm{Cr}$-labelled microsphere technique. Mar Ecol Prog Ser 9:263-271

Taylor RB, Steinberg PD (2005) Host use by Australasian seaweed mesograzers in relation to feeding preferences of larger grazers. Ecology 86:2955-2967

Tuya F, Vanderklift MA, Hyndes GA, Wernberg T, Thomsen MS, Hanson C (2010) Proximity to rocky reefs alters the balance between positive and negative effects on seagrass fauna. Mar Ecol Prog Ser 405:175-186

> Valiela I, McClelland J, Hauxwell J, Behr PJ, Hersh D, Foreman K (1997) Macroalgal blooms in shallow estuaries: controls and ecophysiological and ecosystem consequences. Limnol Oceanogr 42:1105-1118

> Vanderklift MA, Wernberg T (2008) Detached kelps from distant sources are a food subsidy for sea urchins. Oecologia 157:327-335

Vanderklift MA, Kendrick GA, Smit AJ (2005) Differences in trophic position among sympatric sea urchin species. Estuar Coast Shelf Sci 66:291-297

> Vonk JA, Middelburg JJ, Stapel J, Bouma TJ (2008) Dissolved organic nitrogen uptake by seagrasses. Limnol Oceanogr 53:542-548

Wallace JB, Eggert SL, Meyer JL, Webster JR (1999) Effects of resource limitation on a detrital-based ecosystem. Ecol Monogr 69:409-442

Wernberg T, Kendrick GA, Phillips JC (2003) Regional differences in kelp-associated algal assemblages on temperate limestone reefs in south-western Australia. Divers Distrib 9:427-441

> Wernberg T, Vanderklift MA, How J, Lavery PS (2006) Export of detached macroalgae from reefs to adjacent seagrass beds. Oecologia 147:692-701

Submitted: March 13, 2011; Accepted: August 25, 2011

Proofs received from author(s): January 16, 2012 